\title{
Witches, Bitches and Femmes Fatales: Viewing the Female Grotesque in Children's Films
}

\author{
Kerry Mallan
}

'The body is an object of spectacle' (Arthurs 1999, p.143)

$\sqrt{ }$ omen and girls have long been cautioned about making a spectacle of themselves. To do so means to transgress a sanctioned code of femininity, a code which is defined in terms of the restrictions imposed on the female body: its clothing, movements, sounds and appearance. The female body as grotesque spectacle is a mark of excess: too much makeup, outrageous clothes, loud laughter, and behaviour which flaunts the limits of physicality, sobriety and sexuality. By transgressing the norms of femininity, the female grotesque refuses the limits imposed on her body and embraces the ambivalent possibilities such transgressions offer. Invariably, nomenclatures are used to mark the transgressive woman: femme fatale, witch, bitch, hysteric, nymphomaniac. Girls who refuse the restrictions imposed by female dress codes and behaviour are often referred to as 'tom boys' - a phase which is seen as transitory. These names seek to control excessive displays through censure and marginalisation. Yet, despite these social and sexual controls, women and girls continue to transgress the bounds of 'proper' femininity and feminine decorum. Their bodies then become the sites of personal pleasure as well as offering a sight for other women and girls to engage in a voyeuristic delight in seeing the un/sightly; that is, in seeing female bodies performing in ways which are denied to them.

Whilst the female screen presence has traditionally been viewed as the object of the male gaze, spectacles of transgressive women open up a discursive space for the female gaze and for female desire towards the 'other'. The relationship between the viewer and the viewed is not a simple matter of a subject-object dialectic. Rather, the relation of the female viewer to the female on the screen is one of double vision - of seeing the other as the same, familiar and known, yet at the same time, different, unfamiliar and unknown. In real life, women who make a spectacle, through their over-the-top or over-display of actions or costume, transform the fernale body from a site/sight as object to be looked at, to one of 'looking-atbeing-looked-at-ness' (Diamond, in Aston 1995, p.93). In film, the actor/character performs for the camera which becomes both filter and viewer, and whilst the female performer may be denied the opportunity to look at the viewer looking at her, the female viewer is afforded moments of viewing another woman which resonates with representations of self, albeit an imaginary or idealised self. In the case of animation, there are often instances whereby the character acknowledges her delighting in spectacle and being-looked-at by semiotic performative acts such as winks, nods, and come-hither looks and gesturing - acts which can be read as ironic, parodic and complicitous. This notion of the image and the construction of subjectivity (both for viewer and viewed) is central to any discussion concerning female visual pleasure which can be derived through film, television, and magazines. The construction of viewer subjectivity is not simply a matter of identification, but a complex interplay between self and other, and between self and imaginary self which goes beyond the running time of the film.

This paper looks at various representations of female transgression in relation to three popular children's films: The Little Mermaid (1989), The Witches (1989) and 101 Dalmatians (1996). Female grotesques in children's films are largely drawn from literary and cultural stereotypes (eg. the witch, and the evil woman who lures, controls, and conspires). The nature of the genre and its intended audience mean that the narrative is played out within a moral framework - a framework which adults deem suitable for children, hence the ' $G$ ' or 'PG' rating. Whilst such a framework sets up simplistic and familiar binaries (eg. good/evil; male/female; youth/age) the cultural ambiguities which are implicit in the codes and conventions of film suggest possibilities for interpreting the charisma of the characters and their gender representations, as well as for seeing the ways in which irony or kitsch can be employed as destabilising narrative and visual devices. These devices have the potential to both disrupt and corrupt familiar and conventional ways of viewing and responding. In discussing representations of the female grotesque, I want to consider them not in the convention of the cautionary tale of just-deserts, but as possible sites/sights of pleasure for young female viewers. It is not only the physical attractiveness of screen characters, but their parodying and embodying of fernininity through gestures, voice, dress, hairstyle, make- 
up, sensuousness, and their rebellious and transgressive acts that offer a source of subversive viewing pleasure and illicit desire.

For the purposes of this paper, the female grotesque is the dominant term, though another word, hysteric, is also central to the discussion. As Curti points out, "the discourse of hysteria has been central in the definition of woman, both in medical science and in psychoanalysis' (1998, p.112). The hysterical woman is another common image in film, literature, opera and art. The hysteric, like the grotesque, also deviates from 'the norm', though she is more a deviation from the masculine norm of rational thought, controlled action, and accepted feminine decorum. The woman who rants and raves has lost the ability to discipline her body and voice. The association between woman and hysteria is a pervasive one and is often used as 'proof' of woman's emotional proclivity.

As the comments above suggest, society has a largely negative view of the grotesque, hysterical woman. However, the transgressive female body has been appropriated into some feminist theories as a positive symbol of female subversiveness and rebelliousness against patriarchal hierarchies. Whilst I am not suggesting that the films discussed in this paper have been produced with that particular feminist orientation, they can be viewed within a feminist framework. This alternative way of viewing will hopefully open up a space for the pleasure of the female gaze and for the representation of female desire.

\section{TRANSGRESSIVE BODIES: SITES/SIGHTS OF SPECTACLE AND PLEASURE}

The three films under discussion feature grotesque female characters who act as counterpoints to the more sedate and rational (child/teenage) protagonists. Disney previously produced an animated version of 101 Dalmatians in 1961, but it is the 1996 version of Dodie Smith's original text that is of interest in this paper. Whilst the female antagonist, Cruella DeVil, is outnumbered by her canine co-stars (who can be read as children-in-fur), she holds centre stage as the evil, vain and greedy villain who has a fetish for dalmatian fur. Her fetishism is symptomatic of the obsessive nature and manic behaviour attributed to the female hysteric who will resort to anything to satisfy her desires.

The Little Mermaid, based on the Hans Christian Andersen story, is typical of the sanitising process books undergo when they are retold in terms of Disney ideology. There is not the space within this paper to examine the transitions and transformations from book to film, though, as others have shown, such an examination offers a fertile field of investigation (see Zipes 1983; Bell 1995). The hero(ine) of the story is a teenager called Ariel who initially is fascinated with the human world which exists above and beyond her underwater home. This fascination is quickly transformed after a 'love at first sight' encounter with the handsome Prince Eric. Ariel trades her voice (the mark of her identity) to the sea witch, Ursula, for a human body and access to Prince Eric's world and as way of fulfilling her desire for a heterosexual relationship.

The Witches is based on the novel by popular children's writer, Roald Dahl. This story centres on a young boy's attempts to rid the world of witches, a particularly evil form of supernatural being who masquerade as women and who, in turn, want to rid the world of children.

The stereotypical characterisations of the female protagonists and antagonists in these films ensure that, at a superficial level, youth and goodness will win out over (middle) age and wickedness. There are, however, ambivalences within the aesthetics of the films which suggest other possibilities. For instance, beauty becomes an interesting construct which offers different interpretations of conventional and unconventional physical attractiveness. This is most apparent in the use of well-known film stars such as Angelica Huston as the Grand High Witch (GHW) in The Witches and Glenn Close as Cruella DeVil in 101 Dalmatians. While both characters are made to look outrageous through their costume, hair, and elbow-length gloves (reminiscent of screen sirens of film noir), their familiar star images blur the distinctions between fact and fiction, actor and character, conventional and unconventional beauty. This is particularly so for older (adult) viewers who may 'know' the stars and are familiar with their lifestyles and previous film roles. Such knowledge serves to mediate the viewing experience. In the case of younger female 
viewers, glamorous screen females (both good and evil) may offer identificatory pleasure based on fantasy and idealisation. The consumption of visual images may not necessarily be a passive act, as young females may actively delight in negotiating and experimenting with the various possibilities such images offer in terms of constructing subjectivity or a sense of self and other, or self and imaginary self.

Integral to females' outrageousness, and a significant aspect of the aesthetics, is the inevitability of excess and parody. This is apparent in the three films. In 101 Dalmatians, there are similarities between Close's character and that of her earlier role as the avenging, outof-control seductress (Alex Forrest) in Fatal Attraction (1987). Both characters are femmes fatales for whom lust replaces reason: Cruella lusts for dalmatian fur while Alex lusts for men's bodies. Their out-of-control behaviour disrupts conventional images of the restrained female by their aggressive, often hysterical actions and by their conceiving of acts of extreme physical or emotional cruelty: acts which literally centre on skinning 'alive' objects of affection and love (cf. boiling the child's pet bunny in Fatal Attraction and skinning the puppies for their fur in $10 \%$ Dalmatians). Further, both characters are portrayed as 'bitches'. Alex is called 'bitch' by other characters because of her refusal to accept rejection. Cruella's bifurcated hair colour and clothing in black and white are metonymic of her split subjectivity - as a woman and as a hybrid form of both animal and human. She is both literally and metaphorically represented as a bitch in the ways she transgresses female decorum and in her physical similarity to, and passion for, dalmatians. Even Cruella's DeVil's name is a lessthan-subtle reference to her cruel, demonic nature.

In the opening scenes to both The Witches and 101 Dalmatians, The Grand High Witch and Cruella are established as objects of the gaze, as enigmas, and possibly dangerous women. Both make their entrances by way of a limousine, which is in itself a symbolic reference to their place within a luxury milieu. In 101 Dalmatians, the camera tracks the limousine from a high point and when it draws to a halt, a close-up focuses the viewer's attention on the personalised number plate 'DE VIL' - the first link in the metonymic chain which establishes Cruella as a femme fatale. By withholding the whole character, Cruella is gradually revealed in terms of her parts - the long cigarette holder, a black-gloved hand, black stockinged legs in high stiletto shoes, a long trailing animal fur coat, a black hat. The viewer's gaze is directed up and down the body of the woman by the tilt of the camera. Even before the camera reveals the occupant of the limousine, the sound cues the viewer by providing advance notice of what or who is to come. The clichéd music that forebodes who is about to be revealed, directly appeals to the target audience who is familiar with comic book-style films which use music to underscore dramatic action, create atmosphere and signify particular character types.

In The Witches, the viewer first encounters the GHW in her human guise as Miss Ernst. She, too, alights from her limousine, but instead of a slow tracking up and down the body, the camera initially provides a long distance shot of her emerging directly from the car so that she is viewed as a whole before moving in to a middle shot. Miss Ernst briefly surveys the surrounds, and then walks assuredly into a hotel lobby while being greeted by a horde of other women (witches) who praise her for her looks ('You look marvellous'). The low-camera angle ensures that the viewer is placed in a similar position to that of the adoring fans who literally are looking up to Miss Ernst/ GHW who appears dominant and powerful. The effect of this opening series of shots is to confirm the character's status and beauty. Initially, it is not so much the character that is before our eyes, but the star herself. The similarity between Huston, the Hollywood star, and the Miss Ernst character is striking. For example, there has been no attempt to alter Huston's trademark hairstyle - long, black, with a fringe - to suit 'the look' of the character. It is only when Miss Ernst and the other witches are locked in their conference room that the Huston/Ernst persona is discarded and the hideous 'real' character, the GHW, emerges from beneath the human mask. This unveiling before the eyes of the viewer works to erase Huston/Miss Ernst and, in so doing, erases the subject 'woman'. Woman does not exist, but is an illusion, a constructed image, a trompe l'oeil. The use of close-ups on Huston's face before her mask is lifted, serves to fix the gaze of the viewer on the woman as object of desire. 
However, the face we see is also carefully masked with the expert application of cosmetics - white painted skin, vivid red lipstick, black eyeliner and mascara, pencilled, plucked and perfectly-arched eyebrows. As Doane suggests, 'Womanliness is a mask which can be worn or removed' (1991, p.25).

Ursula, the Sea Witch in The Little Mermaid is an animated character who was modelled on the drag queen Divine (Sells 1995). Ursula's camp performance with its stylised gestures, clothing, and theatricality is a pastiche drawing on familiar Hollywood images, styles, and camp icons' (Sells 1995, p.182). Her actions as she sings and moves her body in provocative poses mimic that of the lounge singer. Dressed in a low-cut, long, black evening dress which trails into the tentacles of her octopus being, Ursula, like Cruella, is a hybrid - half woman, half animal. Ursula's transgressive body, with its fetishising of the breasts and hips, is not only at odds with the slender, post-pubescent body of Ariel, but represents a caricature of the female form and, as such, parodies the femme fatale iconography. The parodying of the femme fatale as seductress is explicit in both actions and words. Her voluptuous and fleshy body spills out of her dress and slides and falls into various sexy poses. She sings in fullbodied voice her lament about her current situation as outcast and out-sized: 'Now look at me wasted away to practically nothing, banished and exiled and practically starving'. The words work against the visual, rendering the scene an amusing point of contradiction through irony and kitsch. As Bell suggests, Ursula "not only captures the melodramatic, languorous, and rapacious movement of the diva, but her octopus tentacles physically manifest the enveloping, consumptive sexuality of the deadly woman' (1995, p.117). Ursula's short, bleached, butch hairstyle is another point of disruption of the image of the femme fatale who is usually represented as having long, flowing hair which falls seductively across part of the face similar to that of the red-haired character played by Rita Hayworth in the film Gilda (1946). Ursula's dress, cool demeanour and song, with its undeniable sexual undertones, are reminiscent of Hayworth's character as the night club singer whose song $P u t$ the blame on Mame 'attributes various types of natural and other disasters to female sexuality' (Doane 1991, p. 104).
Clearly, both characters are presented as dangerous women who are not to be trusted. They are also women who delight in their bodies as sensual and transgressive objects of desire which demand the kind of 'looking-at-beinglooked-at-ness' pleasure previously suggested by Diamond. The Gilda image sits comfortably within the Divine reading offered by Sells. By viewing their performances as camp, their flamboyant and parodic representations can be discussed in terms of gender construction, performance, and reception.

Both Ursula and Cruella exaggerate their version of femininity and in doing so reveal feminine identity as always a 'masquerade' (Sells 1995; Doane 1991). In masquerading as the femme fatale, they parody as well as embody familiar female images and stereotypes. These playful representations of sensual, yet comical females serve both to mock the male gaze and to invert the usual male-centred comic paradigm.

Another source of pleasure that can be derived from the femme fatale lies partly in the woman's uninhibited displays of sexuality and the power this generates. This ability is not lost on young adolescent girls who, in their attempts at self-transformation, mimic the bodily posturings and clothing of popular cultural figures such as the Spice Girls. Ursula, Cruella and the GHW dress provocatively. Their make-up, coiffure and exotic clothes are a combination of artifice and sensuality. By drawing attention to the face (especially the mouth and hair) and the body shape, the women are represented as erotic objects. In one scene, Cruella, silhouetted against an elaborate set, stamps her foot and laughs long and raucously and is iconic of the female hysteric. The camera maintains a long-distanced, though steady focus on the corsetted and constricted figure that contorts with laughter. Consequently, framing, costume and lighting combine to offer a stylised representation of the female body as the ultimate screen spectacle that demands a 'tobe-looked-at-ness'.

In addition to the visual and aural pleasures the characters evoke through their looks, movements and voice, there is also a tactile impact suggested by their cosmetically made-up faces and the highly tactile fibre of their clothes - Cruella's fur and sequined gowns, Ursula's silky, 
flowing evening dress, and the GHW's sleek, bodyhugging black dress. The cosmetic mask holds the viewer's gaze, yet supplies a surface which is both seductive and deceptive in the way it disguises its beneath-the-surface evil secrets (Mulvey 1996). These contrasting images and binary oppositions of softness and hardness, beauty and deception evoke both fantasy and fetishism for the viewer.

The three characters are not simply presented as passive and exhibitionist objects of desire as they also exercise considerable control over a group of lackeys who are ever ready to carry out their evil plans. In 101 Dalmatians, a tongue-in-cheek interchange between Cruella and one of her henchmen captures the type of power these women have and the eagerness their subordinates show in order to please (and appease) them:

Cruella: 'What kind of sycophant are you?'

Henchman: 'What kind of sycophant do you want me to be?'

The flip-side of the powerful, out-of-control female is that their transgressions are short-lived and, ultimately, the moral order is restored. The fall of the grotesque is often torturous and protracted, yet occurs within a humorous sequence of events. It is this point at which the grotesque body is shown in the 'spasms of death' or near annihilation that resembles Bakhtin's (1968) concept of carnival. The carnivalesque antics offer spectacles which invariably provoke raucous and subversive laughter from child viewers. Such carnivalesque images, with their connotations of contempt and loathing as well as exhilaration and hilarity are necessarily ambivalent from a feminist viewpoint.

It is through the double-edged notion of 'space' and women's place/position in space, that one can read the liberatory aspects of the carnivalesque against its repressive and retributive side. In her discussion of the philobat or aerial artist as an embodiment of the female grotesque who is both 'up there' and 'out there', Russo refers to the 'aerial sublime' as a 'figure of contradiction', 'an embodiment of possibility and error' (1995, p.29). Her theorisation of the woman whose in-air antics provide a spectacle suggests both danger and thrill. In 101
Dalmatians and The Little Mermaid both Cruella and Ursula perform aerial stunts before their ultimate capture and containment (Cruella) and death (Ursula). Cruella suffers a series of humiliating, yet amazing aerobatics as she is attacked by a band of animals who steal her hat, cause her to slide backwards on the snow with her legs wide apart, fly through the air and land on a stack of hay, wrestle under the weight of a large pig who lands on top of her, and finally is 'tarred and feathered' after falling into a vat of molasses. The result is that the previously glamorous, though eccentric, femme fatale is reduced to a strange alien-like creature barely recognisable through the layers of molasses and hay. However, her portentous claim: 'Cruella has the last laugh', is literalised when the police arrive and announce 'a warrant for your arrest' to which Cruella, in her bedraggled state, replies deadpan: 'Oh, is there something wrong?'. Glenn Close's character survives her ordeal, a fate which is not so for the earlier animated version where Cruella in her car drives off the edge of a cliff. These violent, yet humorous antics can be viewed as embodying the spirit of carnival. The carnivalesque language and actions of the grotesques and their companions are a departure from the norms of decency and etiquette enacted by the other wholesome characters.

Ursula is destroyed when Prince Eric drives the broken ship's mast into her body. Given her femme fatale image. the phallic symbolism of such a fate is an ironic device. In the minutes leading up to Ursula's demise, she dominates both screen time and space. Her body transmogrifies in both shape and size and sweeps upwards. Phallic-like and screaming, Ursula rises above the sea, heavenward, causing a violent storm and huge waves. This climactic series of events is intensified by both the dramatic dark colour scheme of the night sky and the instrumental diegetic accompaniment. Thus, vision and sound reinforce the high point of the grotesque's hysteria and her disruption of the equilibrium of the natural order.

The death of the GHW is also violent resulting in complete obliteration. Tricked into taking her own formula, which was intended to turn children into rats, she undergoes a torturous transformation which is visually depicted as her turning from her beautiful, Huston/Miss Ernst persona 
into a shrunken version of her grotesque GHW self. The body is not only changed, but so too is her voice. High pitched and squealing, the hysterical creature has a glass jug placed over her. The jug serves to both trap and silence her. When it is lifted, she is stomped to death by the male hotel owner. The confinement of the female hysteric to a cell, room or tower is a familiar motif and a warning as to the consequences of women's transgressive actions.

As the above discussion has suggested, space in all three films acts as a metaphoric site of emotional flux and fragmentation. It is in their movements within both open and closed spaces that the grotesques experience the highs and lows of their emotional states. The opening scene of The Witches with its panoramic, aerial sweep of snow-covered mountains provides the viewer with a sensory, elated experience of flight. In the open space that exists above the land, the witches revel in their free and unencumbered state. It is when they transform their beings into the bodies of women that their movements and appearance need to be contained and changed. There is an ironic inversion occurring in that as they become the 'other' (a woman), their own 'otherness' (as witches) is taken as the norm from which they need to deviate. In the early scenes in both 101 Dalmatians and The Little Mermaid, Cruella and Ursula are shown in their own space/place - the office and underwater cave-home. Both places are exotic and surreal in their design and decor and signify the 'otherness' of their owners. The behaviour of Cruella and Ursula in these enclosed spaces is more a display of mild hysteria as opposed to the extravagant emotional outbursts towards the climactic points of the narratives where the characters move in the open spaces of the farmyard and the night sky. In their home space, the characters' lusty and sinister laughter is excessive, unsettling and dominating and serves as a hierarchical separation between the grotesques and the other characters who appear to only snigger, chuckle or smile. When they move into the open spaces their laughing is replaced by screaming, ranting and raving. It is in these moments of high hysteria that child-viewers are given a tantalising mix of fear and pleasure. These out-of-control women offer contrasting images to the more familiar ones of the virgin, the domestic and the maternal and, as such, destabilise and deconstruct femininity as a monolithic category. Paradoxically, however, their very monstrosity and the ways in which they are destroyed continue to reinforce the phallocentric order.

\section{DISCURSIVE SHIFTS IN THE VIEWING PLEASURE}

As this discussion has suggested, the femme fatale and the female grotesque in the three films defy patriarchal values, yet are defined by them and as such offer ambivalent, discursive spaces and pleasures for female viewers. In their defiance of patriarchy, the female grotesques represent the opposite of the 'good' woman and as such set up competing fernininities: Ariel versus Ursula; Anita versus Cruella; grandmother versus the GHW. These oppositions constitute a series of displacements across a number of intersecting discourses and discursive practices, viz. maternity, performativity, and comedy.

Given that all three films are marketed for the child/ family audience, the grotesque is constructed in opposition to the maternal which is seen as natural and normal. The woman/mother identity is described by Haas as the overdetermination of woman via biological function and societal expectation' (1995, p.194). Whether the mother is present, absent or replaced by a woman acting in loco matris, motherhood is a recurring motif in fairy tales and films for children.

In The Witches, the young boy loses both his parents in a car accident in the early part of the narrative. However. from the opening scenes it is clearly evident that his society-parents are rather detached from him and it is his grandmother who loves and cares for him. The point is further reinforced by the boy's apparent lack of grieving at the loss of his parents. Ariel's mother is absent in The Little Mermaid, and her father is shown as the modernday single parent struggling to control the independent spirit of his teenage daughter. 101 Dalmatians is the only film where motherhood is both an essential narrative pivot and an effect of excess. Though there are not as many mothers as dogs in the film, there is, nevertheless. a good supply: Anita (the human mother) gives birth to one child and is pregnant with another by the film's end; 
Perdita (the bitch) gives birth to 15 puppies; the Nanny is a mother substitute for Anita and her husband and is the midwife who assists Perdita in delivering her babies. This excess of mothers serves little function other than to highlight women as reproductive conduits for their mates. The virility of the male dog (and father) Pongo is praised by the human father-to-be as being the essential element in Perdita's ability to give birth to 15 puppies. By contrast, Perdita's weakness in not being able to sustain high levels of energy throughout the long birth is seen as the reason for the near death of one of the puppies. It is left to the human male to give life back to the puppy.

While Nanny, Anita, and Perdita are portrayed in stereotypical supportive roles to their male partners or employer, and offer suitable nurturing presences, there is, nevertheless, a shift in the discourse of maternity as desirable and natural to one which shows the non-maternal figure as someone who has independence, power and wealth. This going against-the-grain-of- motherhood constitutes a subversive viewing pleasure. Ariel, however, offers a more problematic reading. Though the film concludes with her confidently and romantically moving along the path towards matrimony (and presumably motherhood), she achieves a level of independence and freedom from her father's control and that of Ursula who can be read as a perverse, maternal figure (Sells 1995). Ariel's character suggests conflicting images of female independence. Whilst she defies the paternal, she moves towards the paternal in the form of Prince Eric the potential husband/father replacement. Further, her willingness to give up her 'voice' is symbolic of woman's silence as an oppressive part of their history and domination by patriarchy. That it is another woman who takes her voice further serves to reinforce the binary oppositions between the two women by portraying Ursula as more masculine than feminine. However, such masculine tokenism attributed to Ursula is transitory as she is eventually silenced and destroyed. Any feminine allegiance or mother-daughter bonding between Ursula and Ariel is short lived. Ursula's death and Ariel's marriage are seen by Sells as Disney's 'bizarre erasure of "the feminine" and 'the expropriation of women from the mother's genealogy to the father's' (1995, p. 179).
Further contradictions and shifts occur in the ways the films overtly attempt to position viewers within a discourse of maternity as desirable, yet through carnivalesque humour offer a subversive and amusing subtext which parodies child/mother themes and imagery. This is achieved by explicitly contrasting the maternal and the anti-maternal. Cruella, Ursula and the GHW are shown as the antithesis to the nurturing, reproductive woman. From the beginning of The Witches, the grandmother warns her grandson of the witches' hatred for children 'Witches spend their time plotting to kill children'. Just in case the point is overlooked, she later emphasises, 'Witches hate children'. Furthermore, witches find that they cannot bear to be within smelling distance of children. Whereas mothers find that their children 'smell of raspberries and cream', for witches they smell 'like dog's droppings'. Holding their noses and looking nauseous, the witches are barely able to cope with the close proximity of children. Cruella is portrayed as similarly hating children. When Anita announces to her that she is pregnant, Cruella offers her condolences: 'Oh, you poor thing. I'm so sorry'. As a way of emphasising her independent, female status, she later declares proudly: 'I have no use for babies'. Cruella and the GHW both share a similar goal - the annihilation of the young. The GHW announces: '... every child in England shall be rubbed out, destroyed. Every single child eliminated'. Cruella, as she hunts down the missing puppies, gleefully declares: 'I love the smell of near extinction'. Dogs' droppings also come up in this film and serve as a reminder of babies' inability to control their bodily functions and the demands of motherhood (parents) in having to deal with it without complaint. As Cruella carefully picks her way through the snow, avoiding the copious excreta left by the puppies, she holds her nose and curses the "bunch of infant dogs' and having to traipse 'through sewerage'.

Despite these clear messages about the grotesque's loathing of children and motherhood, there are parodic moments in two of the films which offer a playful reference to both the issue and the characters' awareness of their own transgressive natures. For instance, Cruella snuggles into the fur of a Siberian tiger (which she previously had skinned) and coos: 'You were a big, bad boy weren't you, darling?'. Ursula, with mock-sorrow 
and a touch of motherese, mourns the death of her two faithful eels: 'My babies. My poor little poopsies'. These self-referential, ironic scenes demand a 'looking-at-mebeing-maternal' type of spectacle and incite a further shift in viewer allegiance by foregrounding and making fun of the discourses which inscribe the maternal body as loving and protective of her children.

A final feature of viewing pleasure, which signifies a displacement from the discourses of respectable femininity and performativity, lies in the ways the grotesques demand the viewer's gaze through their transgressive feminine acts and costume. Cruella's high-street fashion is a sharp contrast to Anita's demure and conservative clothing. The lack-lustre appearance of Anita, while offering a safe and sensible presence, fails to distract the spectator's gaze away from Cruella. Similarly, the GHW's beauty and figure-enhancing black dress demand a 'to-be-lookedat-ness' which grandmother's pastel-coloured, matronly clothes and comfortable body shape could never command, despite the GHW being much older. The artifice of feminine accoutrements (make-up, hairstyle, clothes) is a point of contrast between the 'natural' looks of the grandmother and the 'unnatural' persona of Miss Ernst whose cosmetic mask hides her ugly, ancient, true self. However, in the case of Ariel and Ursula, the viewer constantly shifts her gaze from one to the other. Ursula's presence cannot be ignored; her body is a sign of excess, in terms of her bulk, her ego, her greed, and her vociferousness. Yet, Ariel's sweet voice, coquettish looks, petite mermaid body with its seashell bra, and long flowing hair will undoubtedly appeal to adolescent girls. It is when the two females are in the same scene that the characters compete for the viewer's gaze and there is a sliding between sameness and difference. This is most apparent when Ursula adopts a maternal/big sister/ girlfriend role and instructs Ariel on the use of make-up and the ways in which to perform femininity. This is a moment of complicity between the two female characters and the female viewer as its lively spectacle of song, dance and posturing highlights the 'performative' nature of gender identity (Sells 1995; Butler 1990). Sells sees Ursula's 'camp drag queen' performance as a strategy for 'denaturalising' gender and foregrounding its 'imitative structure' (1995, p. 183). As a form of ironic representation, camp's attention to feminine artifice and excess, as witnessed in this scene, is a powerful means for critiquing stereotypical images of women and gender identity. Though the female characters do not seek to dismantle gender identity, their 'masquerading' of femininity shows their willingness to play the gender game in order to achieve their own desires(Doane 1991). The scene disrupts the male gaze and offers a site of female viewing pleasure which would be familiar to many girls who enjoy 'dressing up', dancing and singing in the privacy of their bedrooms away from the derisive comments and censorious viewpoint of brothers and their male friends.

\section{CONCLUSION}

By drawing upon the image of the female grotesque and its various manifestations as witch, bitch and femme fatale, this paper has attempted to provide a feminist reading of the negative image of grotesque women by considering some possible avenues for female viewing pleasure and the articulation of female desires. Whilst feminists such as Doane would argue that it is doubtful that a female spectatorship can exist, she also concedes that the pressures to view film and respond to it differently are great: '.. the pressure to find pleasure, the pressure to laugh, the pressure not to feel excluded from the textual field of a dominant mass culture' (1991, p.42). As Doane argues, feminism must continue to read/view/respond to film differently, but at the same time not be blinded to the 'problems posed by a feminist aesthetics and by the concept of subjectivity as it is articulated within representation' (p.42)

The representations of the female grotesque in children's films offer both pleasure and fear as well as rebelliousness and suppression. It is largely through the humour of the carnivalesque in the three films that such contradictory or ambivalent responses work both for and against a positive feminist reading of the grotesque. Nevertheless, Bakhtin's analysis of the space for both celebration and subversion opened up by the masquerade of carnival offers a way of viewing the transgressive and pleasurable potential of the female grotesque. The cultural violations performed by Cruella, Ursula and the GHW break away from the repressive constraints of female bodily decorum and desire. One of the undoubted sites of female viewing 
pleasure lies in the free and uninhibited expression of emotion and desire. The female characters are all hedonistic, vain, greedy and self-centred. Whilst these traits may not necessarily be ones that viewers would want to emulate, they serve a positive function nevertheless. Narcissistic displays have been condemned for centuries and expressions of self-love and selfappreciation have been seen as negative rather than positive attributes. From the early fairy tales, young girls learn of vanity, and its associated wickedness, through the evil step-mother in Snow White who gazes at herself in the mirror and asks if she is still the fairest. This motif is humorously repeated in 101 Dalmatians when Cruella asks a similar question of her mirror, but quickly and unequivocally answers: 'You are'. The notion of the beautiful and nice is given ample attention in the form of heroines such as Ariel, but the beautiful and not-nice is the other woman beyond the mirror. Whereas the beautiful and nice girl/woman would never admit to her own attractiveness, her beautiful and not-nice counterparts such as the GHW and Cruella are clearly aware of the power of their appeal, and provide a subversive alternative.

The three female grotesques focused upon in this paper offer child/adolescent viewers similar moments of humour and shock that many adults find in the comedic performances of characters such as Patsy and Edina in the British television series Absolutely Fabulous. As the transgressions of the female grotesques in the children's films are ultimately repressed and suppressed, it appears that they are unable to break away from the traditional archetypes from which their original book sources have drawn so heavily. The in-roads made by female comedians, filmmakers and writers are a strong indication that the future holds more promise for offering young/adolescent viewers female grotesques whose transgressive potential will not be curtailed, and whose outrageous performances will disrupt existing cultural norms and bring into question those aspects of femininity which are rarely questioned.

\section{REFERENCES}

Andersen, H. C. (1837/1974) 'The little mermaid', in The Complete Fairytales and Stories. Trans. E.C. Haugaard. New York, Doubleday.
Arthurs, J. \& Grimshaw, J. (eds) (1999) Women 's Bodies: Discipline and Transgression. London, Cassell.

Arthurs, J. (1999) 'Revolting women: the body in comic performance', in J. Arthurs \& J. Grimshaw (eds) Women's Bodies: Discipline and Transgression. London, Cassell, pp. 137-164.

Aston, E. (1995) AnIntroduction to Feminism and Theatre. London, Routledge.

Bakhtin, M. (1968) Rabelais and his World. Trans. H. Iswolsky. Cambridge, Massachusetts, MIT.

Bell, E., Haas, L. \& Sells, L. (eds) (1995) From Mouse to Mermaid: The Politics of Film, Gender, and Culture. Bloomington, Indiana University Press.

Bell, E. (1995) 'Somatexts at the Disney shop: constructing the pentimentos of women's animated bodies', in E. Bell, L. Haas, \& L. Sells (eds) From Mouse to Mermaid: The Politics of Film, Gender, and Culture. Bloomington, Indiana University Press, pp.107-124.

Butler, J. (1990) Gender Trouble. New York, Routledge.

Curti, L. (1998) Female Stories, Female Bodies: Narrative, Identity and Representation. London, Macmillan.

Dahl, R.(1985) The Witches. Harmondsworth, Middlesex, Puffin.

Doane, M. (1991) Femmes Fatales: Feminism, Film Theory, Psychoanalysis. New York, Routledge.

Haas, L. (1995) "“Eighty-six the Mother": murder, matricide, and good mothers', in E. Bell, L. Haas, \& L. Sells (eds) From Mouse to Mermaid: The Politics of Film, Gender, and Culture. Bloomington, Indiana University Press, pp. 193-211.

Mulvey, L. (1996) Fetishism and Curiosity. Bloomington and Indianapolis, Indiana University Press.

Russo, M. (1995) The Female Grotesque: Risk, Excess and Modernity. New York, Routledge.

Sells, L. (1995) "'Where do the mermaids stand?": voice and body in The Little Mermaid', in E. Bell, L. Haas, \& L. Sells (eds) From Mouse to Mermaid: The Politics of Film, Gender, and Culture. Bloomington, Indiana 
University Press, pp.175-192.

Smith, D. (1956) The Hundred and One Dalmations. London, Heinemann.

Zipes, J. (1983) Fairy tales and the Art of Subversion. New York, Routledge.

\section{FILMS}

Fatal Attraction (1987) Paramount Pictures.

Gilda (1946) Columbia.

The Little Mermaid (1989) Disney Enterprises (videorecording).

IOI Dalmatians (1996) Disney Enterprises (videorecording).

The Witches (1989) Lorimar Film Entertainment (videorecording).

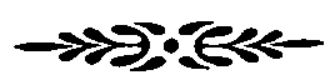

\section{BIOGRAPHICAL NOTE}

Kerry Mallan is a Senior Lecturer in the School of Cultural and Language Studies at Queensland University of Technology. Her research interests include representation of gender and sexuality in youth literature and film, illustration in visual texts for children, and oral narrative and performance. Her most recent publication is In the Picture: Perspectives on Picture Book Art and Artists, published by Centre for Information Studies, C.S.U.

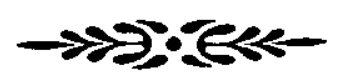

Papers 10: 12000 